\title{
Perilaku Kewirausahaan Pelaku Usaha Pempek Skala Industri Kecil dan Menengah di Kota Palembang, Provinsi Sumatera Selatan
}

\section{Behavioral Enterpreneurship of Pempek Bussiness Actors of Medium and Small Industry Scale in Palembang City, South Sumatera Province}

\author{
Nia Nurfitriana ${ }^{1}$, Anna Fatchiya ${ }^{2}$, Djoko Susanto ${ }^{2}$ \\ ${ }^{1}$ Kementerian Kelautan dan Perikanan Republik Indonesia, Jakarta \\ ${ }^{2}$ Departemen Sains Komunikasi dan Pengembangan Masyarakat, Fakultas Ekologi Manusia, \\ Institut Pertanian Bogor, Bogor
}

\begin{abstract}
Center of business pempek in medium small scale in the Palembang city being in the Seberang Ulu region. Their businesses hardly developed because of the absence a willingness to develop business. For most important is able to fulfill daily needs. The purpose of this research to analyze: (1) characteristics of behavioral entrepreneurship business actors pempek, (2) relations respondents characteristics and supporting factors with the behavioral entrepreneurship (3) relations the success of pempek business with behavioral entrepreneurship. This research was conducted in May-June 2015 in Seberang Ulu I and Seberang Ulu II in Palembang city. Numbers of samples are 50 respondents sets in purposive. Descriptive and Pearson correlational analysis was used to explain this research. The results indicated that the behavioral entrepreneurship of pempek business actors was low, because four of six characteristics behavioral entrepreneurship are confidence, oriented duties, leadership, and results, and originally was low. Characteristics respondents and supported factors were positively correlated with behavior entrepreneurship. Behavioral entrepreneurship was positively correlated with the success of business because behavioural entrepreunership will affect in the amount of sales, the percentage profit, and the amount of labor used.
\end{abstract}

Keywords: Behavior, bussiness actors, entrepreneurship, pempek, small and medium industries

\begin{abstract}
Abstrak
Sentra usaha pempek skala Industri Kecil dan Menengah (IKM) di Kota Palembang berada di wilayah Seberang Ulu. Usaha tersebut tidak dapat berkembang karena tidak adanya keinginan untuk mengembangkan usaha. Hal yang terpenting bagi pelaku usaha, dapat memenuhi kebutuhan sehari-hari dengan usaha tersebut. Penelitian ini menganalisis: (1) ciri-ciri perilaku kewirausahaan pelaku usaha pempek, (2) hubungan karakteristik responden dan faktor pendukung dengan perilaku kewirausahaan (3) hubungan perilaku kewirausahaan dengan keberhasilan usaha pempek. Penelitian dilakukan di Wilayah Seberang Ulu di Kecamatan Seberang Ulu I dan Seberang Ulu II Kota Palembang, pada Bulan Mei-Juni 2015. Sampel ditetapkan secara sengaja sebanyak 50 orang. Metode analisis yang digunakan adalah secara statistik deskriptif dan korelasi Pearson. Hasil penelitian menunjukkan perilaku kewirausahaan pelaku usaha pempek rendah karena empat dari enam ciri-ciri perilaku kewirausahaan yaitu kepercayaan diri, berorientasi tugas dan hasil, kepemimpinan, dan keorisinilan rendah. Karakteristik responden dan faktor pendukung dengan perilaku kewirausahaan memiliki hubungan positif sangat nyata. Perilaku kewirausahaan dengan keberhasilan usaha berhubungan positif sangat nyata karena perilaku kewirausahaan mempengaruhi besarnya jumlah penjualan, persentase keuntungan, dan jumlah tenaga kerja.
\end{abstract}

Kata kunci: Perilaku, pelaku usaha, kewirausahaan, pempek, industri kecil dan menengah

\section{Pendahuluan}

Produksi pempek merupakan Industri Kecil dan Menengah (IKM) yang paling banyak diusahakan di Kota Palembang. Hal ini terkait dengan budaya makan pempek pada masyarakat Palembang yang mengakibatkan realisasi angka konsumsi ikan di Provinsi Sumsel yang tinggi mencapai $35,31 \mathrm{~kg}$ / kap/thn melebihi realisasi rata-rata angka konsumsi ikan nasional sebesar 33,89 kg/kap/tahun di tahun 2012 (Kementerian Kelautan dan Perikanan, 2013).
Konsumsi pempek di Kota Palembang mencapai total 243,91 ton yang terdiri dari pempek basah sebesar 484.73 ton dan pempek kering sebesar 59,18 ton per bulan pada tahun 2010 (DKP Provinsi Sumsel, 2012). Terdapat berbagai jenis pempek di antaranya lenjer, kapal selam, panggang, lenggang, kulit, otak-otak, tahu, keriting, telur, pastel, adaan maupun pempek kreasi seperti pempek sosis sapi, pempek baso sapi, dan pempek lenggang keju (Disperindagkop Kota Palembang, 2011).

Pemasaran pempek cukup luas baik domestik

${ }^{1}$ Korespondensi penulis 
maupun luar negeri, bahkan pesanan pempek online melalui PT Pos Kota Palembang terhitung awal Desember 2013 mengalami peningkatan. Pemesanan pempek rata-rata $100 \mathrm{~kg}$ per bulan sebelum Desember 2013 menjadi rata-rata 2,5-3,5 ton pada tahun 2014 . Saat ini pemesanan pempek online mencapai 8 ton per bulan baik tujuan domestik maupun mancanegara khususnya negara-negara ASEAN seperti Malaysia, Singapura, dan Thailand.

Peluang pasar pempek yang begitu besar di KotaPalembang belum diimbangi dengankemampuan pelaku usaha pempek di Wilayah Seberang Ulu yang merupakan usaha berskala IKM. Hal ini disebabkan berbagai kendala di antaranya adalah total produksi hanya berkisar 5-10 $\mathrm{kg}$ perhari, sarana pengolahan terbatas salah satunya freezer, jaringan pemasaran yang masih terbatas dengan mengandalkan para pelanggan dan pedagang eceran lokal yang berkisar di Kota Palembang, promosi produk juga masih terbatas sekedar promosi dari mulut ke mulut, variasi produk olahan pempek yang terbatas, dan motivasi pengembangan usaha yang rendah sekedar untuk memenuhi kebutuhan sehari-hari sehingga usaha berskala IKM tersebut tidak dapat mengembangkan usahanya dengan baik. Keberlanjutan usaha bukan berarti mengembangkan usaha menjadi skala yang lebih besar, tetapi yang terpenting bagaimana usaha tersebut dapat bertahan dan dapat memenuhi kebutuhan sehari-hari.

Berdasarkan hal tersebut, perilaku kewirausahaan pelaku usaha pempek yang berhubungan langsung dengan keberhasilan usahanya merupakan sesuatu yang menarik untuk diteliti. Selain itu, karakteristik responden meliputi umur, jumlah tanggungan keluarga, motif usaha, sumber belajar, pendidikan formal, pendidikan non formal, pengalaman berusaha, dan dukungan keluarga serta faktor pendukung yang terdiri dari dukungan bahan baku, kondisi lingkungan tempat usaha, dan pendampingan dan pembinaan usaha oleh pemda termasuk hal-hal penting untuk diteliti hubungannya dengan perilaku kewirausahaan.

Terdapat enam ciri-ciri wirausaha sukses yaitu kepercayaan diri, berorientasi pada tugas dan hasil, keberanian mengambil resiko, kepemimpinan, keorisinilan, dan berorientasi ke masa depan (Meredith, 1996). Hal ini juga selaras dengan hasil penelitian yang menyatakan bahwa rendahnya kemandirian untuk keberhasilan usaha merupakan salah satu ciri-ciri wirausaha yang sukses (perilaku kewirausahaan) berhubungan positif dengan rendahnya karakteristik responden (karakteristik pribadi) dan faktor pendukung (dukungan lingkungan usaha) pelaku usaha sebagai pengrajin kulit di Sidoarjo dan Magetan, Jawa Timur (Sumardjo dan Utami, 2006). Menurut Firmansyah dan Bachtiar (2010) rendahnya kreativitas dan inovasi (perilaku kewirausahaan) termasuk ciri wirausaha sukses berhubungan positif dengan rendahnya keberhasilan usaha kecil pelaku usaha sebagai pengrajin perak di

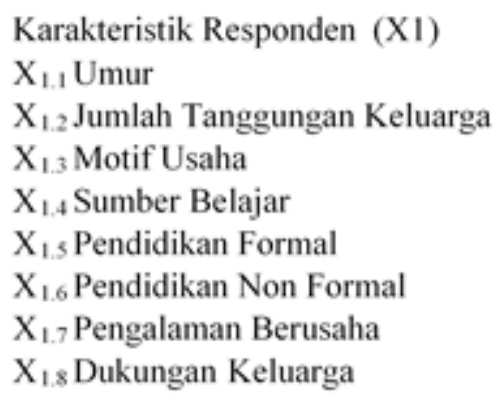


Kotagede dan Kasongan Yogyakarta.

Penelitian ini mengkaji lebih jauh perilaku kewirausahaanpelakuusahapempekdiKotaPalembang guna meningkatkan kinerja dalam pengembangan usaha. Tujuan penelitian ini adalah: 1) Menganalisis ciri-ciri perilaku kewirausahaan pelaku usaha pempek;

2) Menganalisis hubungan karakteristik responden dan faktor pendukung dengan perilaku kewirausahaan pelaku usaha pempek; dan 3) Menganalisis hubungan perilaku kewirausahaan dengan keberhasilan usaha pelaku usaha pempek.

\section{Metode Penelitian}

Desain penelitian merupakan survey yang terfokus pada Explanation. Penelitian Eksplanasi digunakan untuk menjelaskan faktor-faktor yang diduga berhubungan dengan perilaku kewirausahaan pelaku Industri Kecil dan Menengah (IKM). Faktor tersebut meliputi peubah terikat (perilaku kewirausahaan $\left(\mathrm{Y}_{1}\right)$ dan keberhasilan usaha $\left(\mathrm{Y}_{2}\right)$ ) dan peubah bebas (karateristik responden $\left(\mathrm{X}_{1}\right)$ dan faktor pendukung $\left(\mathrm{X}_{2}\right)$ ). Lokasi penelitian ditetapkan di Wilayah Seberang Ulu yang terdiri dari Kecamatan Seberang Ulu I terdiri dari Kelurahan 1 Ulu, 2 Ulu, 3/4 Ulu, 5 Ulu, 7 Ulu, 8 Ulu, 9/10 Ulu dan Kecamatan Seberang Ulu II terdiri dari Kelurahan 11 Ulu dan 12 Ulu Kota Palembang. Pemilihan daerah ini dilakukan secara sengaja (purposive) karena alasan dan pertimbangan bahwa lokasi ini merupakan Sentra Industri Kecil dan Menengah (IKM) Makanan Khas Palembang termasuk pempek.

Penelitian lapang dilakukan pada bulan MeiJuni 2015. Populasi penelitian merupakan pelaku usaha pempek skala IKM. Jumlah sampel adalah 50 orang pelaku usaha dengan teknik pengambilan responden dilakukan secara purposive (sengaja). Data yang digunakan dalam penelitian ini meliputi data primer dan data sekunder.Analisis data pada karakteristik responden, faktor pendukung, dan perilaku kewirausahaan diolah dengan ditabulasikan dan dijelaskan secara kualitatif. Untuk melihat hubungan setiap variabel X1 dan X2 terhadap variabel $\mathrm{Y} 1$ dan variabel $\mathrm{Y} 1$ terhadap variabel Y2 dianalisis menggunakan korelasi Pearson dengan memanfaatkan software SPSS 20.

\section{Hasil dan Pembahasan}

\section{Karateristik Responden}

Karateristik pelaku usaha pempek Industri
Kecil dan Menengah (IKM) didominasi oleh umur kategori sedang (46-60 tahun), jumlah tanggungan keluarga didominasi kategori sedang (4-6 orang), motif usaha didominasi sebagai penghasilan utama, dan sumber belajar didominasi oleh diri sendiri.

Pendidikan formal didominasi kategori rendah (tidak tamat SD-tidak tamat SMP), pendidikan non formal didominasi tidak pernah mengikuti, pengalaman usaha didominasi kategori rendah (0-15 tahun) dan dukungan keluarga didominasi kategori sedang (4,1-6) (Tabel 1).

Umur pelaku usaha pempek yang menjadi responden dalam penelitian ini didominasi umur 4660 tahun sebesar 50\% yang dikategorikan sedang. Umur tersebut tidak termasuk pada usia muda namun masih pada usia produktif sehingga pelaku usaha masih mempunyai kemampuan fisik untuk melakukan usaha pempek. Hal ini sejalan dengan hasil penelitian Setiawan et al. (2006) yang mengungkapkan bahwa kemampuan fisik, psikologis dan biologis seseorang berhubungan dengan umur dari orang tersebut. Data dari 50 responden pelaku usaha pempek di Kecamatan Seberang Ulu I dan Seberang Ulu II skala IKM di Kota Palembang menggambarkan bahwa responden didominasi oleh jenis kelamin perempuan sejumlah 31 orang, sedangkan jenis kelamin laki-laki hanya sejumlah 19 orang. Jenis kelamin atau gender tersebut berpengaruh pada kesungguhan berwirausaha, seperti yang dikatakan Crant (1996) bahwa gender berpengaruh terhadap intensi wirausaha. Pelaku usaha laki-laki mempunyai sifat yang lebih proaktif dibanding perempuan. Pelaku usaha yang proaktif lebih mudah bergaul sehingga mempunyai banyak relasi, oleh karena itu dapat cepat menyesuaikan diri dan fleksibel dalam melihat peluang untuk mengembangkan usahanya.

Menurut hasil pengamatan dan wawancara pada umur 46-60 tahun tergolong telah memiliki banyak pengalaman yang berkaitan dengan usaha pempek baik itu pernah menjadi karyawan atau pegawai usaha pempek maupun ikut membantu orang tua atau kerabat yang membuka usaha pempek. Pengalaman tersebut akhirnya membuat mereka memiliki kemampuan dalam membuat pempek serta berpengaruh terhadap banyaknya jaringan produsen bahan baku maupun konsumen atau pelanggan.

Jumlah tanggungan keluarga merupakan banyaknya anggota keluarga atau orang lain yang tinggal satu atap dan menjadi tanggungan responden. 
Tabel 1. Jumlah dan Persentase berdasarkan Kategori Karateristik Pelaku IKM

\begin{tabular}{|c|c|c|c|}
\hline Peubah & Kriteria & $\begin{array}{c}\text { Jumlah } \\
\text { Responden }\end{array}$ & $\begin{array}{c}\text { Presentase } \\
(\%)\end{array}$ \\
\hline \multirow{3}{*}{ Umur } & Muda (31-45 tahun) & 20 & 40 \\
\hline & Sedang (46-60 tahun) & 25 & 50 \\
\hline & Tua (61-75 tahun) & 5 & 10 \\
\hline \multirow[t]{3}{*}{$\begin{array}{l}\text { Jumlah Tanggungan } \\
\text { Keluarga }\end{array}$} & Rendah (1 - 3 orang) & 22 & 44 \\
\hline & Sedang (4 -6 orang) & 25 & 50 \\
\hline & Tinggi (7 - 9 orang) & 3 & 6 \\
\hline \multirow[t]{3}{*}{ Motif Usaha } & Waktu Luang & 1 & 2 \\
\hline & Usaha Tambahan & 16 & 32 \\
\hline & Penghasilan Utama & 33 & 66 \\
\hline \multirow[t]{9}{*}{ Sumber Belajar } & Ide Usaha Pempek & & \\
\hline & Saudara/Kerabat & 9 & 18 \\
\hline & Orang Tua & 13 & 26 \\
\hline & Motivasi Diri Sendiri & 28 & 56 \\
\hline & Mengolah Pempek & & \\
\hline & Saudara/Kerabat & 12 & 24 \\
\hline & Orang Tua & 18 & 36 \\
\hline & Diri Sendiri (otodidak) & 20 & 40 \\
\hline & $\begin{array}{l}\text { Rendah (tidak Tamat SD- tidak } \\
\text { tamat SMP) }\end{array}$ & 24 & 48 \\
\hline \multirow{2}{*}{ Pendidikan Formal } & Sedang (SMP - tidak tamat SMP) & 22 & 44 \\
\hline & Tinggi (SMA- Univ) & 4 & 8 \\
\hline \multirow{2}{*}{ Pendidikan Non Formal } & Pernah & 10 & 20 \\
\hline & Tidak Pernah & 40 & 80 \\
\hline \multirow{3}{*}{ Pengalaman Berusaha } & Rendah $(0-15$ thn $)$ & 37 & 74 \\
\hline & Sedang (16 - 30 thn) & 11 & 22 \\
\hline & Tinggi $(31-45$ thn $)$ & 2 & 4 \\
\hline \multirow[t]{3}{*}{ Dukungan Keluarga } & Rendah (2-4) & 17 & 34 \\
\hline & Sedang (4,1-6) & 19 & 38 \\
\hline & Tinggi $(6,1-8)$ & 14 & 28 \\
\hline
\end{tabular}

Sumber: Data Olahan, 2016

Responden dalam penelitian ini didominasi memiliki tanggungan keluarga sejumlah 4-6 orang yang dikategorikan sedang sebesar 50\%. Tanggungan keluarga responden selain istri, suami, dan anak juga orang tua, mertua, adik, kakak, sepupu, keponakan atau yang masih memiliki hubungan kerabat. Sebagian besar responden hanya menanggung istri/suami, anak, dan orang tua/mertua. Mereka hanya menumpang tempat tinggal serta kebutuhan sehari-hari saja seperti makan, uang jajan dan uang kebutuhan sekolah seperti membeli seragam, buku, dan sumbangan untuk sekolah bagi kebutuhan anak mereka. Sehingga, pengeluaran setiap harinya masih mencukupi dari penghasilan yang diperoleh dari usaha pempek.

Motif usaha merupakan tujuan utama responden dalam memulai atau mendirikan usaha pempek. Responden yang menjadikan usaha pempek sebagai penghasilan utama sebesar $66 \%$. Hal ini membuktikan bahwa responden masih menjadikan 
Tabel 2. Distribusi Pelaku Usaha Pempek di Kota Palembang berdasarkan Faktor Pendukung Pelaku Usaha Pempek

\begin{tabular}{llcc}
\hline \multicolumn{1}{c}{ Peubah } & \multicolumn{1}{c}{ Kriteria } & Jumlah Responden & Persentase (\%) \\
\hline Bahan Baku & Tidak Mudah & 3 & 6 \\
& Mudah & 47 & 94 \\
Dukungan Lingkungan & Rendah $(3-4)$ & 33 & 66 \\
& Sedang $(4,1-5)$ & 12 & 24 \\
& Tinggi $(5,1-6)$ & 5 & 10 \\
Pendampingan dan & Rendah $(2-3,7)$ & 28 & 56 \\
Pembinaan Usaha oleh & & & \\
Pemda & & 21 & 42 \\
& Sedang $(3,8-5,4)$ & 1 & 2 \\
\hline Singgi $(5,5-7)$ & & \\
\hline
\end{tabular}

Sumber: Data Olahan, 2016

usaha pempek sebagai penghasilan utama untuk memenuhi kebutuhannya sehari-hari bukan hanya sekedar mengisi waktu luang atau hanya sebagai penghasilan tambahan saja. Responden yang menjadikan pempek sebagai usaha tambahan biasanya memiliki usaha yang lain seperti usaha kerupuk/kempelang dan usaha penjualan ikan segar di pelelangan ikan yang menghasilkan pendapatan lebih besar dibandingkan usaha pempek. Usaha pempek hanya dijadikan sebagai usaha tambahan disaat usaha utama mereka mengalami penurunan penjualan. Responden memilih usaha pempek sebagai sumber mata pencarian utama karena membuka usaha ini tidak memerlukan modal yang besar untuk bahan baku dan tempat usaha, hanya memanfaatkan tempat tinggal mereka tanpa harus mengeluarkan biaya sewa tempat mengingat responden didominasi oleh skala usaha mikro atau rumah tangga.

Sumber belajar merupakan asal ide responden dalam memulai usaha pempek dan sumber pembelajaran dalam pengolahan pempek. Inspirasi dalam memulai usaha pempek dan sumber belajar dalam pengolahan pempek didominasi bersumber dari diri sendiri sebesar 56\%. Hal ini dikarenakan perjalanan hidup yang telah dilalui responden sebelum memulai usaha pempek pernah bekerja dengan orang lain, atau sekedar membantu orang tua dalam menjalankan usaha pempek. Oleh karena itu dalam proses pengolahan pempek pelaku usaha belajar secara otodidak tanpa mengikuti pelatihan maupun kursus atau sengaja diajarkan oleh orang lain.

Sebesar $48 \%$ responden memiliki pendidikan tidak tamat SD-tidak tamat SMP sehingga usaha pempek menjadi sumber penghasilan utama. Peningkatan kemampuan kewirausahaan responden dapat ditunjang dengan pendidikan non formal, namun sebesar 80 persen responden tidak pernah mengikuti pelatihan karena tidak adanya interaksi dengan pemda setempat mengingat sebagian besar skala usaha responden merupakan skala mikro atau rumah tangga. Dilihat dari pengalaman berusaha diketahui hampir 75 persen responden dalam kategori rendah (0-15 tahun). Pengalaman yang dimiliki seseorang akan menjadi referensi dalam mengambil suatu keputusan pada setiap tindakannya. Hal ini sejalan dengan pendapat Bandura (1986) bahwa pengalaman masa lalu seseorang dapat menentukan konsekuensi masa depannya. Oleh karena itu suatu pengalaman dapat menentukan perilaku seseorang. Penelitian yang dilakukan Pambudy et al., (2011) juga menghasilkan bahwa pengalaman berwirausaha mempengaruhi perilaku wirausaha mahasiswa IPB.

Dukungan keluarga termasuk dalam kategori sedang. Dukungan keluarga merupakan keterlibatan anggota keluarga responden dalam mendukung usaha pempek yaitu keterlibatan sebagai tenaga kerja dan memberi masukan atau saran positif yang berkaitan dengan pengembangan usaha pempek. Menurut Rosenblatt, de Mik, Anderson dan Johnson yang dikutip oleh Greve dan Salaff (2003), anggota keluarga memainkan peranan penting saat seseorang wirausaha merencanakan dan mendirikan usaha, karena anggota keluarga dan jaringannya selalu dilibatkan untuk dimintai dukungan dan bantuannya. Tenaga kerja dalam penelitian ini merupakan tenaga 
kerja tetap yang melibatkan suami/istri dan anak maupun kerabat baik dengan upah per hari maupun hanya berupa uang rokok atau uang jajan saja.

\section{Faktor Pendukung Perilaku Kewirausahaan Pelaku Usaha Pempek Skala IKM}

Sebesar 94\% responden menyatakan bahwa bahan baku untuk membuat pempek dalam kategori mudah diperoleh. Bahan baku yang diperoleh tidak mudah yaitu ikan sebagai salah satu bahan baku utama karena bersifat musiman terutama bagi responden yang cenderung konsisten menggunakan bahan baku 1 jenis ikan saja. Pelaku usaha pempek skala mikro biasanya menggunakan ikan kakap. Ikan kakap merupakan salah satu ikan laut yang dijual dengan harga murah, namun saat musim gelombang tinggi dan nelayan jarang melaut ikan kakap terkadang sulit didapat dan terjadi kenaikan harga. Harga ikan kakap biasanya lebih murah dari pada ikan tenggiri.

Sebesar 66\% dukungan lingkungan tempat usaha baik infrastruktur maupun keterlibatan warga sebagai tenaga kerja tergolong dalam kategori rendah. Keterlibatan warga merupakan pemberdayaan warga sekitar lingkungan tempat usaha sebagai tenaga kerja. Sebagian responden menyatakan bahwa tidak pernah terlibat sama sekali mengingat sebagian responden hanya mengandalkan keluarganya saja, terutama suami/istri dan anak sehingga pengeluaran tidak begitu besar.

Hal ini dikarenakan skala usaha responden hanya mikro atau rumah tangga. Responden terkadang melibatkan warga sekitar apabila pesanan sedang berlimpah. Menurut observasi atau pengamatan peneliti di beberapa kelurahan terdapat lingkungan tempat usaha yang kotor dengan selokan yang dipenuhi dengan sampah serta bau yang tidak sedap. Selain itu, kondisi jalan setapak yang hanya bisa dilewati oleh pejalan kaki dan motor yang berarti akses menuju tempat usaha yang kurang strategis.

Hal yang belum terealisasi dengan baik yaitu proses pendampingan dan pembinaan bagi pelaku usaha pempek yang masih dalam kategori rendah (Tabel 2). Pendampingan dan pembinaan usaha oleh pemda mengenai pembinaan usaha dapat dilihat dari berbagai kegiatan yang diselenggarakan pemda melalui pendidikan non formal bagi responden. Selain itu, pendampingan usaha dalam penelitian ini yaitu pemda memberikan informasi mengenai peluang kerjasama atau kemitraan dengan pihak lain dan bantuan sarana. Bantuan sarana merupakan pendampingan usaha yang biasanya dilakukan oleh pemda Provinsi Sumatera Selatan khususnya Kota Palembang yang rutin setiap tahun. Lebih dari separuh responden menyatakan bahwa pemda tidak melayani dalam memberikan informasi kemitraan kepada pelaku usaha dan tidak pernah sama sekali mendapatkan bantuan sarana. Sebesar 50\% dari 22 responden yang mendapatkan bantuan sarana menyatakan bahwa Pemda tidak melayani, sekedar memberikan bantuan saja.

Hal ini membuktikan bahwa hubungan antara pelaku usaha pempek di Kecamatan Seberang Ulu 1 dan Seberang Ulu II dengan pemda setempat baik Kota Palembang maupun Provinsi Sumsel tidak erat, karena pada kecamatan tersebut skala usaha pempek yang dominan berskala mikro atau rumah tangga, sehingga belum tersentuh oleh pelayanan pemda. Pemda setempat biasanya memberikan bantuan sarana kepada IKM yang baru mulai berkembang. Menurut hasil wawancara di lapangan, semakin erat hubungan pelaku usaha dengan pemda maka pelaku usaha tersebut yang diprioritaskan untuk mendapatkan bantuan sarana. Keeratan hubungan tersebut diperoleh melalui keterlibatan pelaku usaha dalam berbagai kegiatan yang diadakan oleh Pemda, seperti pertemuan dan pameran maupun bazaar. Selain itu, pelaku usaha pempek di Kecamatan Seberang Ulu 1 dan Seberang Ulu II belum teorganisir dalam wadah kelompok sehingga sulit untuk memberikan bantuan secara objektif dengan prioritas pelaku usaha yang sangat membutuhkan.

\section{Perilaku Kewirausahaan}

Ciri perilaku kewirausahaan pelaku usaha pempek di Kecamatan Seberang Ulu I dan Seberang Ulu II secara keseluruhan rendah. Hal ini disebabkan karena empat dari enam ciri-ciri perilaku kewirausahaan berada pada kategori rendah (Tabel 3). Ciri-ciri kewirausahaan tersebut adalah kepercayaan diri, berorientasi tugas dan hasil, kepemimpinan, dan keorisinilan.

Kepercayaan diri responden tergolong rendah. Menurut hasil wawancara mendalam bahwa responden tidak memiliki kepercayaan diri atau keyakinan untuk mengembangkan usahanya, termasuk mengikuti kegiatan pameran/bazaar, karena yang terpenting 
Tabel 3. Distribusi Pelaku Usaha Pempek di Kota Palembang berdasarkan Kategori Ciri-ciri Perilaku Kewirausahaan

\begin{tabular}{|c|c|c|c|c|}
\hline No & Perilaku1 Kewirausahaan & Kategori & $\begin{array}{l}\text { Jumlah } \\
\text { (orang) }\end{array}$ & $\begin{array}{c}\text { Persentase } \\
(\%)\end{array}$ \\
\hline \multirow{3}{*}{1} & \multirow{3}{*}{ Kepercayaan diri } & Rendah(3-6) & 35 & 70,00 \\
\hline & & Sedang (7-9) & 12 & 24,00 \\
\hline & & Tinggi (10-12) & 3 & 6,00 \\
\hline \multirow{3}{*}{2} & \multirow{3}{*}{ Berorientasi tugas dan hasil } & Rendah(2-3,3) & 33 & 66,00 \\
\hline & & Sedang $(3,4-4,6)$ & 9 & 18,00 \\
\hline & & Tinggi $(4,7-6)$ & 8 & 16,00 \\
\hline \multirow{3}{*}{3} & \multirow{3}{*}{ Berani mengambil resiko } & $\operatorname{Rendah}(2-3,7)$ & 14 & 28,00 \\
\hline & & Sedang $(3,8-5,4)$ & 28 & 56,00 \\
\hline & & Tinggi $(5,5-7)$ & 8 & 16,00 \\
\hline \multirow{3}{*}{4} & \multirow{3}{*}{ Kepemimpinan } & Rendah(4-6,3) & 33 & 66,00 \\
\hline & & Sedang $(6,4-8,6)$ & 11 & 22,00 \\
\hline & & Tinggi $(8,7-11)$ & 6 & 12,00 \\
\hline \multirow{3}{*}{5} & \multirow{3}{*}{ Berorientasi masa depan } & Rendah(4-6,7) & 20 & 40,00 \\
\hline & & Sedang $(6,7-9,4)$ & 29 & 58,00 \\
\hline & & Tinggi $(9,5-12)$ & 1 & 2,00 \\
\hline \multirow{3}{*}{6} & \multirow{3}{*}{ Keorisinilan } & Tidak Pernah (1) & 31 & 62,00 \\
\hline & & Jarang (2) & 14 & 28,00 \\
\hline & & Sering dan Rutin (3) & 5 & 10,00 \\
\hline \multirow{3}{*}{7} & \multirow{3}{*}{$\begin{array}{l}\text { Total perilaku } \\
\text { kewirausahaan }\end{array}$} & Rendah $(31-48,3)$ & 34 & 68,00 \\
\hline & & Sedang $(48,3-65,6)$ & 11 & 22,00 \\
\hline & & Tinggi $(65,6-83)$ & 5 & 10,00 \\
\hline
\end{tabular}

Sumber: Data Olahan, 2016

dapat menjalani usaha setiap harinya dan perputaran modal berjalan lancar walaupun tidak menghasilkan keuntungan yang besar. Sebagian besar pelaku usaha tidak ikut berpartisipasi dalam kegiatan pameran/bazaar karena pemda setempat tidak pernah mengundang pelaku usaha untuk ikut serta dan bagi pelaku usaha kegiatan tersebut tidak begitu bermanfaat.

Tanpa harus mengikuti pameran maupun bazaar usahanya tetap berjalan. Berorientasi tugas dan hasil juga termasuk dalam kategori rendah. Menurut responden mencatat laporan keuangan bukan merupakan sesuatu yang dianggap berpengaruh pada usahanya karena yang terpenting setiap harinya dapat menghasilkan keuntungan walaupun sedikit. Promosi dalam pengembangan usaha mereka hanya mengandalkan promosi mulut ke mulut karena promosi melalui media membutuhkan modal yang besar sedangkan modal yang dimiliki masih terbatas.

Berani mengambil resiko termasuk dalam kategori sedang. Lebih dari setengah responden termasuk dalam kategori ini. Menurut hasil wawancara, para responden sebagian besar berencana membuka cabang tapi hal tersebut belum diwujudkan dalam tindakan yang nyata hanya sebatas wacana saja dan kemasan produk pempek baik plastik maupun kardus tergolong kemasan yang sederhana karena keterbatasan modal yang dimiliki. Lebih dari 3/5 dari jumlah responden termasuk dalam kategori rendah untuk kepemimpinan. Keterbukaan terhadap kerjasama dan berbagi ilmu dengan orang lain masih sangat terbatas. Hal ini karena pelaku usaha tidak memiliki kepercayaan yang baik terhadap orang lain bahkan akan menanggung dampak negatif yang dihasilkan misalnya kerugian usaha.

Keorisinilan tergolong rendah karena sebesar $62 \%$ responden tidak pernah sama sekali berinovasi untuk mengolah pempek jenis baru. Apabila berinovasi pun responden hanya mencoba dan hanya untuk diri sendiri, tidak untuk diperdagangkan. Lebih dari 50\% responden termasuk kategori sedang dalam orientasi masa depan usahanya. Responden sesekali menabung khusus untuk pengembangan usaha dan adanya rencana dalam meneruskan usaha khususnya kepada anak mereka. Namun, tidak berencana membuka pemesanan online karena keterbatasan dalam menggunakan teknologi 
komputer.

\section{Keberhasilan Usaha}

Keberhasilan usaha pempek diukur dari rataan omset, rataan presentase keuntungan, dan rataan jumlah tenaga kerja. Rataan omset pelaku usaha pempek tergolong rendah karena dominan skala usaha mikro atau rumah tangga walaupun meningkat pada kondisi penjualan sepi, normal, dan ramai. Rataan omset saat kondisi penjualan normal meningkat sebesar $82 \%$ dibandingkan kondisi penjualan sepi. Peningkatan rataan omset saat kondisi penjualan ramai sebesar $116 \%$ dibandingkan kondisi normal karena pemesanan pempek mencapai 2 hingga 3 kali lipat pada saat menjelang puasa, menjelang Idul Fitri, musim acara pernikahan, sunatan, aqiqah, dan acara syukuran lainnya.

Rata-rata keuntungan saat kondisi penjualan normal meningkat sebesar 91 persen dibandingkan kondisi penjualan sepi dan saat kondisi penjualan ramai meningkat sebesat 132 persen dibandingkan kondisi penjualan normal. Hal ini membuktikan bahwa semakin ramai penjualan semakin besar rataan omset dan semakin besar juga rataan presentase keuntungan yang menentukan rataan keuntungan yang dihasilkan oleh pelaku usaha pempek (Tabel 4). Rataan omset yang meningkat mengakibatkan rataan jumlah tenaga kerja juga meningkat walaupun tidak nyata karena sebagian besar responden memiliki jumlah tenaga kerja yang sama besar saat kondisi penjualan sepi, normal, dan ramai. Sehingga, rataan tenaga kerja saat kondisi penjualan sepi, normal, dan ramai tidak berbeda nyata (Tabel 5). Oleh karena itu strategi bisnis pelaku usaha pempek skala IKM untuk meningkatkan jumlah penjualan/omzet tidak melalui peningkatan jumlah tenaga kerja namun penambahan jam kerja yang berpengaruh pada jumlah produksi pempek yang akan dihasilkan perhari.
Tabel 5. Rata-rata Jumlah Tenaga Kerja berdasarkan Kondisi Penjualan

\begin{tabular}{lc}
\hline Kondisi Penjualan & $\begin{array}{c}\text { Rata-rata Jumlah Tenaga } \\
\text { Kerja }\end{array}$ \\
\hline Sepi & 2,8 \\
Normal & 3,0 \\
Ramai & 3,1 \\
\hline
\end{tabular}

Sumber: Data Olahan, 2016

\section{Hubungan antara Karakteristik Responden dengan Perilaku Kewirausahaan}

Karakteristik responden berhubungan positif nyata dan sangat nyata dengan perilaku kewirausahaan. Hubungan positif nyata meliputi pendidikan formal dan non formal, sedangkan berhubungan positif sangat nyata adalah dukungan keluarga (Tabel 6). Hal ini sejalan dengan hasil penelitian Wijaya (2008) bahwa dukungan keluarga berpengaruh positif terhadap perilaku berwirausaha. Dukungan keluarga tersebut khususnya keterlibatan keluarga menjadi tenaga kerja dalam menjalankan usaha pempek. Sebagian besar responden melibatkan istri, suami, dan anak karena tidak membutuhkan upah tetap per harinya berupa uang rokok, uang makan, atau uang jajan.

Pendidikan formal dan non formal memiliki hubungan yang nyata dengan perilaku kewirausahaan. Semakin tinggi pendidikan formal pelaku usaha maka perilaku kewirausahaan mereka semakin baik. Pelaku usaha pempek yang semakin sering terlibat dalam berbagai pendidikan non formal seperti bimbingan teknis, sosialisasi, dan pelatihan/ kursus setahun terakhir akan semakin memiliki perilaku kewirausahaan yang baik. Hal ini senada dengan temuan Soemanto (2002) bahwa pendidikan merupakan upaya atau cara untuk mewujudkan

Tabel 4. Rata-rata Omset dan Rata-rata Keuntungan berdasarkan Kondisi Penjualan

\begin{tabular}{lccccc}
\hline \multirow{2}{*}{$\begin{array}{c}\text { Kondisi } \\
\text { Penjualan }\end{array}$} & \multicolumn{2}{c}{$\begin{array}{c}\text { Jumlah Penjualan/Omzet } \\
\text { (Rp/hari) }\end{array}$} & \begin{tabular}{c} 
Rata-rata \\
Omzet \\
\cline { 2 - 6 } (Rp/hari)
\end{tabular} & $\begin{array}{c}\text { Rata-rata } \\
\text { Presentase } \\
\text { Keuntungan } \\
\text { (persen) }\end{array}$ & $\begin{array}{c}\text { Rata-rata } \\
\text { Keuntungan } \\
\text { (Rp/hari) }\end{array}$ \\
\hline Sepi & 75.000 & 2.000 .000 & 316.837 & 40 & 126.735 \\
Normal & 150.000 & 3.000 .000 & 576.000 & 42 & 241.920 \\
Ramai & 200.000 & 6.000 .000 & 1.245 .000 & 45 & 560.250 \\
\hline
\end{tabular}

Sumber: Data Olahan, 2016 
Tabel 6. Hubungan Karakteristik Pelaku Usaha Pempek di Kota Palembang dengan Perilaku Kewirausahaan

\begin{tabular}{|c|c|c|}
\hline \multirow{2}{*}{ Karakteristik responden } & \multicolumn{2}{|c|}{$\begin{array}{c}\text { Perilaku } \\
\text { Kewirausahaan }\end{array}$} \\
\hline & Korelasi & $\mathbf{P}$ \\
\hline Umur & 0,067 & 0,643 \\
\hline $\begin{array}{l}\text { Jumlah Tanggungan } \\
\text { Keluarga }\end{array}$ & 0,165 & 0,253 \\
\hline Motif Usaha & 0,142 & 0,331 \\
\hline Sumber Belajar & 0,143 & 0,323 \\
\hline Pendidikan Formal & $0,269 *$ & 0,062 \\
\hline Pendidikan Non Formal & $0,256 *$ & 0,073 \\
\hline Pengalaman Berusaha & 0,177 & 0,219 \\
\hline Dukungan Keluarga & $0,504 * * *$ & 0,000 \\
\hline
\end{tabular}

$\mathrm{P}$ : Peluang Kesalahan,

* Berhubungan Nyata pada $\alpha=10 \%$

*** Berhubungan Sangat Nyata pada $\alpha=1 \%$

manusia mempunyai moral, sikap dan keterampilan wirausaha. Pendidikan mampu membuat seseorang menjadi lebih percaya diri, sehingga bisa memilih dan membuat keputusan yang tepat untuk meningkatkan kreativitas dan inovasi baru dalam usahanya.

Umur tidak berhubungan dengan perilaku kewirausahaan karena penambahan umur tidak disertai dengan penambahan informasi dalam menjalankan usaha pempek. Informasi yang diterima terbatas sehingga pelaku usaha pempek tidak dapat mengembangkan skala usaha lebih besar yang pada akhirnya perilaku kewirausahaan tidak mengalami perubahan. Menurut Schramm dan Robert (1971) bahwa dengan adanya informasi dapat memberikan perubahan. Menurut hasil wawancara dengan responden bahwa sebagian responden yang berskala mikro atau rumah tangga tidak memiliki dorongan untuk mengurus Surat Izin Usaha Perdagangan (SIUP) karena mereka mengganggap SIUP hanya membebankan mereka dari segi prosedur pengurusan yang panjang dan biaya pengurusan sehingga mengakibatkan tidak adanya hubungan yang erat dengan pemda setempat. Hal tersebut mengakibatkan sebagian besar responden skala mikro atau rumah tangga tidak pernah dilibatkan dalam pameran/bazaar dan berbagai pelatihan yang tentunya akan berdampak pada penambahan informasi

Sebagian besar motif usaha mereka menjadikan usaha pempek sebagai penghasilan utama. Mereka sudah cukup puas apabila penghasilan dari usaha pempek tersebut dapat memenuhi kebutuhan sehari hari sehingga tidak ada dorongan yang kuat untuk lebih mengembangkan usaha menjadi skala yang lebih besar. Sumber belajar tidak berhubungan dengan perilaku kewirausahaan, walaupun sebagian besar pelaku usaha pempek mendapatkan ide memulai usaha dan mengolah pempek dari diri sendiri yang artinya terdapat dorongan kuat atau motivasi dalam diri, namun kepercayaan terhadap orang lain tergolong rendah. Terbukti dari sebagian besar pelaku usaha pempek tidak mau menjalin kerjasama dengan orang lain karena ketidakpercayaan takut usaha mereka akan dirugikan dan tidak pernah berbagi ilmu yang berkaitan dengan usaha pempek dengan orang lain sehingga dapat diartikan sebagai pribadi yang tertutup atau tidak proaktif. Sementara itu seorang wirausaha membutuhkan pribadi yang proaktif sejalan dengan pendapat dari Seibert et al., (2001) yang menyatakan bahwa kepriadian proaktif berhubungan positif dengan pekerjaannya, menerapkan ide-ide baru di tempat kerja disamping itu individu proaktif terlibat dalam inovasi berkonsentrasi pada solusi dan bekerja untuk mengembangkan dan menerapkan ideide mereka sendiri.

Berdasarkan pengamatan dan wawancara jumlah tanggungan keluarga tidak menjadi beban bagi pelaku usaha pempek walaupun mempengaruhi jumlah pengeluaran rumah tangga sehari hari namun tidak berhubungan dengan perilaku kewirausahaan. Dukungan keluarga terutama keterlibatan keluarga sebagai tenaga kerja dalam membantu menjalankan usaha pempek yang berhubungan sangat nyata dengan perilaku kewirausahaan.

Pengalaman berusaha tidak berhubungan dengan perilaku kewirausahaan. Hal ini disebabkan karena pengalaman berusaha pelaku usaha pempek masih tergolong rendah dan pelaku usaha pempek tidak mengandalkan pengalaman berusaha namun lebih kepada pendidikan formal dan non formal seperti pelatihan.

\section{Hubungan antara Faktor Pendukung dengan Perilaku Kewirausahaan}

Dukungan lingkungan tempat usaha dan 
pendampingan dan pembinaan oleh pemda memiliki hubungan positif sangat nyata dengan perilaku kewirausahaan (Tabel 7). Kondisi lingkungan tempat usaha dalam hal ini berupa keterlibatan warga sekitar sebagai tenaga kerja tetap, atau hanya tenaga kerja pada saat ramai penjualan/pemesanan saja. Selain itu berupa dukungan kondisi infrastruktur lingkungan tempat usaha para pelaku usaha pempek. Apabila kondisi infrastruktur emakin mendukung dan partisipasi warga semakin besar maka kegiatan usaha pempek akan semakin mudah dilakukan. Adanya sarana dan prasarana yang memadai mendukung pelaku usaha untuk membuat keputusan dalam menjalankan usahanya.

Responden menyatakan bahwa keterlibatan warga tersebut pada bagian pengolahan dan atau penjaga warung pempek sebesar $60 \%$ dan selebihnya sebagai pemasok bahan baku ikan atau hanya membantu menjual pempek keliling. Semua responden menyatakan bahwa kondisi infrastruktur lingkungan tempat usaha mereka mendukung usaha pempek.

Pendampingan dan pembinaan usaha oleh pemda dalam penelitian ini behubungan sangat nyata dengan perilaku kewirausahaan. Semakin pemda setempat memberikan bantuan sarana dan informasi mengenai kerjasama dengan pihak lain maka perilaku kewirausahaan responden semakin baik, karena dapat mempermudah responden dalam pengolahan pempek dengan bantuan sarana yang diberikan serta memperluas jaringan pemasaran dengan relasi yang semakin bertambah.

Bahan baku tidak memiliki hubungan dengan perilaku kewirausahaan. Bahan baku pada penelitian ini hanya berupa tingkat mudah dan tidak mudah dalam memperoleh bahan baku pengolahan pempek terutama bahan baku utama berupa ikan dan tepung tapioka (sagu). Sebesar 95\% responden mengatakan bahwa memperoleh bahan baku untuk pembuatan pempek mudah untuk didapatkan di pasar tradisional yang menjadi langganan mereka. Biasanya pasar tradisional tersebut dekat dan mudah dijangkau dari tempat usaha. Bahan baku tidak memiliki hubungan dengan perilaku kewirausahaan karena skala usaha responden masih tergolong skala mikro atau rumah tangga yang memiliki modal terbatas. Keterbatasan modal merupakan hambatan utama dalam kesuksesan usaha maupun bagi seseorang untuk memulai usahanya (Indarti dan Rostiani, 2008). Seseorang yang memiliki akses modal yang cukup, maka kecenderungan untuk membuka usaha baru lebih tinggi. Kondisi ini sejalan dengan hasil penelitian Priyanto (2005) yang menemukan bahwa akses modal menjadi salah satu faktor penentu intensi wirausaha bagi petani tembakau di Jawa Tengah.

Berdasarkan hasil wawancara di lapangan meskipun bahan baku utama (ikan dan tepung tapioka) sangat mudah diperoleh namun modal yang dimiliki responden terbatas sehingga. Pelaku usaha pempek menggunakan bahan baku ikan air tawar dan laut yaitu kakap, gabus, dan tenggiri. Sebesar 90\% reponden menggunakan bahan baku ikan kakap karena harga yang lebih murah dibandingkan dengan gabus atau tenggiri mengingat skala usaha para reponden sebagian besar hanya skala rumah tangga atau mikro. Pelaku usaha pempek yang menggunakan ikan kakap dapat menjual pempek kepada konsumen seharga Rp 700,- hingga Rp 1.000,- per buah. Pelaku usaha yang menggunakan ikan gabus atau tenggiri menjual pempek dengan harga Rp 2.000.- hingga Rp 3.000,- per buah. Pempek dengan bahan baku ikan kakap memiliki rasa dan bau sedikit amis serta tekstur yang sedikit lembek dan licin atau tidak begitu kenyal dibandingkan dengan pempek dengan menggunakan bahan baku ikan gabus atau tenggiri.

Tabel 7. Hubungan Faktor Pendukung dengan Perilaku Kewirausahaan Pelaku Usaha Pempek di Kota Palembang

\begin{tabular}{lcc}
\hline \multirow{2}{*}{ Faktor pendukung } & \multicolumn{2}{c}{ Perilaku Kewirausahaan } \\
& Korelasi & P \\
\hline Bahan Baku & 0,650 & $-0,066$ \\
Dukungan Lingkungan Tempat Usaha & $\mathbf{0 , 4 3 7 * * *}$ & $\mathbf{0 , 0 0 2}$ \\
Kebijakan Pemda Mengenai & $\mathbf{0 , 5 3 5 * * *}$ & $\mathbf{0 , 0 0 0}$ \\
Pendampingan dan Pembinaan Usaha & & \\
\hline P: Peluang Kesalahan & &
\end{tabular}




\section{Hubungan Perilaku Kewirausahaan dengan Keberhasilan Usaha}

Erliah (2007)yang dikutip oleh Muhlisin(2010) mengatakan bahwa suatu usaha dikatakan berhasil di dalam usahanya apabila setelah jangka waktu tertentu usaha tersebut mengalami peningkatan baik dalam permodalan, skala usaha, hasil atau laba, maupun jenis usaha maupun pengelolaannya. Hubungan perilaku kewirausahaan dengan keberhasilan usaha diukur melalui 3 (tiga) peubah yaitu jumlah penjualan (omzet), presentase keuntungan, dan jumlah tenaga kerja. Peneliti tidak menggunakan peubah jumlah konsumen (pelanggan) dan biaya pengeluaran (operasional) karena pelaku usaha pempek tidak melakukan pencatatan laporan keuangan secara detail dan rutin.

Hubungan perilaku kewirausahaan dengan keberhasilan usaha positif sangat nyata dengan $\mathrm{p}$ value sebesar 0,000 dan nilai korelasi 0,638 dengan tingkat kepercayaan 99\%. Hasil penelitian ini sejalan dengan hasil penelitian yang dilakukan oleh Masykuri dan Soesatyo (2013), bahwa terdapat pengaruh positif dan signifikan antara perilaku kewirausahaan terhadap keberhasilan usaha pada UKM pengrajin songkok di Kecamatan Bungah Kabupaten Gresik.

Jumlah penjualan (omzet) memiliki hubungan dengan perilaku kewirausahaan. Hal ini berarti semakin baik perilaku kewirausahaan pelaku usaha pempek maka pendapatan/omzet yang diperoleh semakin besar. Menurut hasil pengamatan temuan yang paling menonjol yaitu tindakan pelaku usaha saat menghadapi kondisi penjualan pempek yang sepi pembeli. Responden yang memiliki perilaku kewirausahaan yang baik cenderung tidak mudah berputus asa untuk menjual pempek dengan cara lain termasuk mencoba menitipkan pempek tersebut kepada orang lain atau berdagang keliling. Disamping itu, mereka juga mencoba meningkatkan produksi jenis barang dagangan yang lain seperti kerupuk/ kelempang, sehingga mereka tidak hanya berdiam diri dan pasrah saja dengan keadaan supaya omzet yang dihasilkan tidak menurun drastis. Responden yang memiliki perilaku kewirausahaan yang baik juga memiliki kebiasaan menabung khusus digunakan untuk pengembangan usahanya terutama disaat kondisi penjualan sedang ramai dan jumlah penjualan (omzet) yang mereka terima lebih besar dari biasanya. Presentase keuntungan atau NPM berkaitan erat dengan perilaku kewirausahaan. Semakin besar presentase keuntungan yang diperoleh semakin baik perilaku kewirausahaan pelaku usaha pempek. Menurut hasil wawancara, hal tersebut karena mereka memiliki motivasi yang tinggi untuk mengembangkan usahanya khususnya rencana untuk masa depan dalam bentuk tabungan atau investasi untuk membuka cabang usaha mereka yang lain.

Tenaga kerja pada penelitian ini merupakan tenaga kerja pada saat sepi, normal, dan ramai yang terbukti memiliki hubungan dengan perilaku kewirausahaan. Semakin banyak jumlah tenaga kerja yang dimiliki oleh pelaku usaha pempek semakin baik juga perilaku kewirausahaan pelaku usaha tersebut. Hal ini terbukti dari hasil pengamatan dan wawancara kepada beberapa responden yang skala usahanya lebih besar daripada responden lainnya biasanya memiliki jumlah tenaga kerja yang lebih banyak dan perilaku kewirausahaannya tergolong tinggi karena mereka lebih memiliki dorongan yang jauh lebih besar untuk mengembangkan usahanya.

Responden yang memiliki perilaku kewirausahaan yang lebih baik dibandingkan responden lainnya cenderung lebih memiliki hubungan yang lebih dekat dengan pemda setempat karena menurut mereka hal tersebut akan berpengaruh terhadap pengembangan usaha mereka termasuk dapat diikutsertakan dalam kegiatan pameran/bazaar yang pada akhirnya dapat menambahjumlah penjualan(omzet) mereka. Selainitu, mereka akan lebih diprioritaskan untuk mendapatkan bantuan sarana dari pemda setempat yang berpengaruh juga terhadap jumlah produksi pempek dan jumlah penjualan mereka.

\section{Kesimpulan}

Perilaku kewirausahaan pelaku usaha pempek skala IKM di Kecamatan Seberang Ulu 1 dan Seberang Ulu 2 yang meliputi kepercayaan diri, berorientasi tugas dan hasil, kepemimpinan, dan keorisinilan dalam kategori rendah, sedangkan berorientasi masa depan dan berani mengambil resiko dalam kategori sedang cenderung rendah.

Karakteristik responden berupa pendidikan formal, pendidikan non formal, dan dukungan keluarga yang semakin tinggi mendukung peningkatan perilaku kewirausahaan yang baik. Demikian pula, faktor pendukung yang berupa dukungan lingkungan tempat usaha dan pendampingan/pembinaan oleh Pemda yang semakin besar mendorong peningkatan perilaku kewirausahaan yang baik pelaku usaha 
pempek skala IKM. Perilaku kewirausahaan yang semakin baik mendorong peningkatan keberhasilan usaha.

Berdasarkan hal tersebut maka perlu: 1) Meningkatkan frekuensi pelatihan dengan materi yang dapat memotivasi pelaku usaha pempek skala IKM agar perilaku kewirausahaan mereka lebih baik, 2) Memfasilitasi kegiatan bazaar/pameran pelaku usaha pempek skala IKM dengan mempermudah akses, 3) Memfasilitasi pelaku usaha pempek skala mikro/ rumah tangga dan skala kecil untuk bekerjasama dengan pelaku usaha pempek skala menengah dalam meningkatkan jaringan pemasaran.

\section{Daftar Pustaka}

Bandura AJ. 1986. Social Foundations of Thought and Action: A Social Cognitive Theory. New Jersey: Prentice Hall, Inc.

Crant JM. 1996. The Proactive Personality Scale As A Predictor Of Entrepreneurial Intentions. Journal of Small Business Management.

[DISPERINDAGKOP] DinasPerindustrian, Perdagangan, dan Koperasi Kota Palembang. Inventarisasi Hasil Budaya Rakyat Palembang (Ekpresi Foklor] Industri Kecil dan Menengah. 2011. Palembang (ID): Bidang Pembinaan Industri.

[DKP] Dinas Kelautan dan Perikanan Provinsi Sumatera Selatan. Statistik dalam Angka. 2012. Palembang (ID): Bidang Pengolahan dan Pemasaran Hasil Perikanan.

Firmansyah, Bachtiar MA. 2010. Hubungan antara Perilaku Inovatif Wirausaha dengan Keberhasilan Usaha Kecil. Jurnal Psikologi Sosial Hubungan Sikap Perilaku: 2(3).

Greve A, Salaff JW. 2003. Social Networks and Entrepreneurship. Entrepreneurship. Theory \& Practice. 28(1): 1-22.

Indarti N, Rostiani N. 2008. Intensi Kewirausahaan Mahasiswa: Studi Perbandingan Antara Indonesia, Jepang dan Norwegia. Jurnal Ekonomika dan Bisnis Indonesia. (23) 4.

[KKP] Kementerian Kelautan dan Perikanan. Pedoman GEMARIKAN. 2013. Jakarta (ID): Direktorat Pemasaran Dalam Negeri, Ditjen
Pengolahan dan Pemasaran Hasil Perikanan.

[KKP] KementerianKelautandanPerikanan.Pedoman Penetapan Penghargaan GEMARIKAN. 2013. Jakarta (ID). Direktorat Pemasaran Dalam Negeri, Ditjen Pengolahan dan Pemasaran Hasil Perikanan.

Masykuri AA, Soesatyo Y. 2013. Analisis Perilaku Kewirausahaan Terhadap Keberhasilan Usaha pada Usaha Keil Menengah (UKM) Pengrajin Songkok di Kecamatan Bungah Kabupaten Gresik. Universitas Negeri Surabaya.

Meredith G. 1996. Kewirausahaan: Teori dan Praktek. Jakarta (ID): Pustaka Binamaan Presindo.

Muhlisin AD. 2010. Pengaruh Perilaku Kewirausahaan dan Kemampuan Manajerial Terhadap Kinerja Usaha (Survey pada Pengrajin Sentra Rajut Binong Jati Bandung). Bandung (ID): Universitas Komputer Indonesia.

Pambudy R, Burhanuddin, Priatna WB, Nia R. 2011. Analisis Perilaku Wirausaha Mahasiswa Institut Pertanian Bogor. Prosiding Seminar Penelitian Unggulan Departemen Agribisnis. 179-196.

Priyanto SH. 2005. Model Hubungan Lingkungan Eksternal-Kewirausahaan Kinerja: Kasus Usahatani Tembakau. Jurnal Bisnis Strategi. 14(1): 52-69.

Schramm W, Robert DF. 1971. The Process and Effects Of Mass Communication. Urbana: University of Illinois Press.

Seibert SE, Kraimer ML, Crant JM. 2001. What Do Proactive People Do? A Longitudinal Model Linking Proactive Personality and Career Success. Personnel Psychology 54(4): 45-74.

Setiawan IG, Asngari PS, Tjitropranoto P. 2006. Dinamika Petani dalam Beragribisnis Salak. Jurnal Penyuluhan 2(47): 44-52.

Soemanto. 2002. Mengaktualisasikan Sikap dan Perilaku Wirausaha. Jurnal Online.

Sumardjo, Utami HN. 2006. Faktor-faktor yang Berhubungan dengan Kemandirian Pengrajin Kulit di Kabupaten Sidoarjo dan Magetan Jawa Timur. Jurnal Penyuluhan 2(4).

Wijaya T. 2008. Kajian Model Empiris Perilaku Berwirausaha UKM DIY dan Jawa Tengah. Jurnal Manajemen dan Kewirausahaan 10 (2): 93-104. 